\title{
Wij zijn sociologen
}

\author{
Willem Trommel
}

Ostaijen, M. van (2018). Wij zijn ons. Een kleine sociologie van grote denkers. Nijmegen: Van Tilt

\section{Een fraai visitekaartje}

Mark van Ostaijen heeft met Wij zijn ons een klein maar fijn boek geschreven, dat zich laat lezen als een hartstochtelijk pleidooi voor de sociologische blik op de wereld. Was dit dan nodig? Nou en of, aldus de auteur, die zich in het inleidende hoofdstuk beklaagt over de alomtegenwoordigheid van het (neuro)psychologische mens- en wereldbeeld. In de media, in het publiek debat, in bestuur en politiek: overal wordt het sociale gereduceerd tot individuele verschijnselen, waaronder steeds vaker de biologie van breinprocessen. Maar: 'Wij zijn niet alleen ons brein. Wij zijn ook niet alleen maar wij. We produceren elkaar, in collectief verband. Daarom: wij zijn ons' (p. 129).

In elf korte, aanstekelijke hoofdstukken laat Van Ostaijen zien wat dit betekent. Hij volgt daarbij een doeltreffend procedé. Eerst wordt een actuele maatschappelijke kwestie geïntroduceerd, dan wordt een klassieke socioloog ten tonele gevoerd, en aan de hand van diens inzichten wordt ten slotte duidelijk gemaakt wat de sociologische zienswijze aan verrassend inzicht te bieden heeft. In de meeste gevallen is dat iets spannends en/of onverwachts, in ieder geval voor de lezer die niet zo vertrouwd is met de denkers die in dit boek de revue passeren. Een aangename bijkomstigheid is dat Van Ostaijen geen scholastiek bedrijft; geput wordt uit een variëteit van sociologische denktradities. Het functionalisme van Emile Durkheim komt voorbij, maar ook het dramaturgisch perspectief van Erving Goffman. We ontmoeten grootheden als Max Weber, Robert Merton en Georg Simmel, maar ook enkele onverwachte personages die wat meer buiten het vakgebied staan, zoals de historicus Johan Huizenga en de stedenbouwkundige journaliste/activiste Jane Jacobs. Ook de aangekaarte kwesties kennen een prettige variëteit: van \#MeToo tot gulzig internet, en van carnaval tot integratieproblematiek.

Wat het boek daarnaast erg levendig maakt, zijn de uitstapjes naar het persoonlijk leven van de auteur. We zien hem rondscharrelen als jonge misdienaar en in een latere levensfase als liefhebber in het voetbalstadion: simpelweg van geloof veranderd. We lezen een kleurrijke schets van zijn achtergrond in het Brabantse land, waar hij als zoon van een huisschilder opgroeit in een arbeiderswijk, met de bijbehorende voorliefde voor André Hazes. En als we dat beeld goed en wel op het netvlies hebben staan, worden we deelgenoot van zijn 'sociale stijging', met een soci-

* Prof. dr. Willem Trommel is hoogleraar beleids- en bestuurswetenschappen aan de Vrije Universiteit van Amsterdam. 
ologiestudie aan de universiteit en een bijbehorende omwenteling in zijn muzikale voorkeuren. Hazes maakt plaats voor Radiohead. Deze biografische noten zijn meer dan smeuïge vertelsels, ze maken dat het boek niet alleen over sociologie gaat, maar ook zelf een boeiend sociologisch vertoog is. Van Ostaijen beschikt in ruime mate over wat Wright Mills de sociologische verbeeldingskracht noemde: het vermogen om een individuele biografie te begrijpen tegen de achtergrond van complexe collectieve processen.

Ik zal de verleiding weerstaan om alle hoofdstukken hier te bespreken. Dat zou bovendien flink wat spoilers opleveren; veel aardiger is het om al lezende de actualiteitswaarde van de sociologie te (her)ontdekken. Laat ik evenwel twee smaakmakers opdienen. De eerste is voor doorgewinterde vakgenoten welbekende kost en gaat over de selffulfilling prophecy van Robert Merton. Een magistraal 'sociaal mechanisme', slim uitgedokterd, het lijkt wel een echte wetmatigheid. Van Ostaijen kan zijn enthousiasme niet onderdrukken wanneer hij uitlegt hoe aan de hand hiervan een scherp licht kan worden geworpen op het fenomeen van de 'bankencrisis'. Dat heeft alles te maken met 'onjuiste overtuigingen' die op steeds grotere schaal opgeld doen en om die reden 'reële consequenties' gaan sorteren. Een mooi lesje, maar oordeelt u vooral zelf. En dan is er het spannende hoofdstuk over radicalisering. Bijzonder is dat de wetenschapper die in dit hoofdstuk centraal staat, de Amerikaans-Iranese Fathali Moghaddam, de enige hoofdfiguur in het boek is die nog in leven is. Moghaddam typeert radicalisering als een trapsgewijs proces, van relatieve deprivatie tot sociaal verzet, en van daaropvolgende bereidheid om geweld te gebruiken tot daadwerkelijke terreur. Deze staircase to terrorism heeft wellicht niet de kracht van een mertoniaanse wetmatigheid, maar opent wel de ogen voor het feit dat terreur allerminst de uitkomst is van een individuele state of mind. Heel vergelijkbaar met hoe Emile Durkheim al in 1897 liet zien hoe een schijnbaar hyperindividuele daad als het plegen van suïcide heel goed kan worden herleid tot 'sociale feiten'.

$\mathrm{Al}$ met al is Wij zijn ons een mooi nieuw visitekaartje voor een oude discipline. Ook als uw belangstelling primair uitgaat naar beleid, bestuur en politiek, biedt het boek behartigenswaardige lessen. Zo verheldert het de sociologische blik waarom snelle en gemakkelijke gedragsinterventies meestal geen hout snijden. Maar al te vaak gaat achter het beleidsprobleem een ingewikkelde sociale dynamiek schuil, die zich niet zomaar laat plooien. Wij zijn niet de optelsom van een groot aantal ikken, wij zijn ons, en 'ons' leidt een eigen leven dat niet, of alleen heel eigenaardig, reageert op individuele gedragsbeïnvloeding. De vraag is wel of dit boek er ook voor zorgt dat zulke lessen toegepast gaan worden in de beleidspraktijk. Is Wij zijn ons meer dan een goed gelukt visitekaartje? Gaat het ook verschil maken? Over deze meer kritische vraag gaat het restant van deze bespreking.

\section{Maar urgent genoeg?}

Wie meer aandacht wil vragen voor sociologie - maatschappelijk, wetenschappelijk, politiek - kan niet heen om de vraag waarom deze aandacht eigenlijk al zo lang tanende is. Hoewel bij uitstek ook een sociologische vraag, stelt Van Ostaijen 
hem niet. Hij hekelt weliswaar het veelvuldig gebruik van het psychologisme, maar besteedt niet veel aandacht aan de achtergronden daarvan. Dat is jammer, want de nu zo populaire paradigma's zijn evengoed het resultaat van allerhande sociale en politieke krachten. Denk aan het systeem van wetenschapsfinanciering, dat bakken geld stuurt naar de neurosciences en de sociologie laat verpieteren. Elders heb ik bredere achtergronden geschetst bij deze teloorgang. Zo is daar de politieke cultuur van het neoliberalisme, met haar heiligverklaring van een hyperindividualistisch mens- en wereldbeeld. We herinneren ons Margaret Thatcher: there is no such thing as society. Tja, dan is er ook geen sociologie. Maar ook die markante tegenbeweging van het populisme, met zijn symboliek rond volk en gemeenschap, heeft opmerkelijk genoeg weinig op met sociologische argumentatie. Sociologen, waren dat niet die politiek correcte gutmenschen die het multiculturele drama lange tijd onder de wetenschappelijke pet hielden...?

Scherper geformuleerd: pleiten voor meer sociologie is tegenwoordig een regelrecht politiek statement, want een oproep om zowel macht als tegenmacht te attaqueren met diepere sociale waarheden. Was dit in vervlogen tijden vooral voorbehouden aan de 'kritische scholen' binnen het vakgebied - veel beleidssociologen werkten inderdaad in dienst van de macht -, nu kan het gebeuren dat zelfs de meest behoudende sociologie in het publieke debat wordt afgefakkeld. Een onschuldige rechte telling van het Sociaal en Cultureel Planbureau waaruit blijkt dat allochtone leerlingen minder kans maken op een stageplek, kan al leiden tot ophef. Daar heb je ze weer, die sociologen met hun vergoelijkende analyses. Fake news! In het gunstigste geval wordt het sociologische geluid nog wel geapprecieerd omdat het altijd zo lekker tegendraads klinkt. Het geeft het volk iets om zich boos over te maken en het maakt de macht aan het lachen. De socioloog als hofnar in een neoliberale huishouding.

Wij zijn ons had iets meer kunnen doen om deze narrenstatus te bestrijden. Bijvoorbeeld door uitvoeriger het debat te zoeken met de in het eerste hoofdstuk betwiste verklaringsschema's. Hoe kijkt een gedragspsycholoog bijvoorbeeld naar de opkomst van het \#MeToo-fenomeen, en wat maakt nu precies dat een sociologische benadering beter en dieper inzicht genereert? Een dergelijke aanpak, consequent toegepast in elk van de hoofdstukken, zou het pleidooi beslist hebben kunnen versterken, maar Van Ostaijen heeft deze weg niet bewandeld en dat is zijn goed recht. Het gevolg is wel dat de meerwaarde van de sociologie niet altijd scherp genoeg voor het voetlicht komt. Een tweede kanttekening betreft de onderwerpkeuze. De stukken over thema's als vrijgezellenfeesten, voetbal en rouwrituelen leveren weliswaar fraaie sociologische miniaturen op - de moeite waard, zoals ik eerder al benadrukte -, maar ze zijn minder geschikt om de urgentie van de sociologische blik op de samenleving voor een breder publiek te onderstrepen. De macrosociologie krijgt weinig aandacht - denk aan de generatie Habermas, Beck, Giddens - en daarmee laat de auteur een kans liggen om de neergang van de sociologie sociologisch te doordenken tegen de achtergrond van bredere maatschappelijke transformaties.

Dit alles laat onverlet dat dit goed geschreven boek veel aandacht verdient. En hopelijk weet het ook in verschillende kringen pleitbezorgers te mobiliseren. De 
tijd lijkt rijp om met kracht van argumenten voor de goede zaak op te komen, niet omdat we l'art pour l'art voorstaan, maar omdat we geloven dat ons vak wezenlijk bijdraagt aan de kwaliteit van wetenschap en samenleving. Dat Mark van Ostaijen met zijn 35 levensjaren tot de jongere generatie vakgenoten behoort, lijkt me een teken van hoop. In een van de hoofdstukken vertelt de auteur hoe hij als eerstejaarsstudent verliefd werd op de elegantie en rijkdom van de sociologische denktrant. Ontroerend en heel herkenbaar, niet alleen voor ondergetekende, maar vast en zeker ook voor vele anderen. Laat dan die liefde van weleer de bron zijn voor een groeiende beweging die de boodschap nieuw leven inblaast. We staan voor sociale wetenschap die, inderdaad, sociaal is. We staan voor een samenleving die, inderdaad, sociaal is. We zijn potdomme geen narren. We zijn strijdbaar en hebben een urgente boodschap. Wij zijn sociologen. 